\section{REFERENCES}

Bett, I. M. (1962). Ann. rheum. Dis., 21, 388.

Biechl, A., Stapleton, J. E., Woodbury, J. F. L., and Read, H. C. (1962). Canad. med. Ass. F., 86, 401.

British Medical Association (1950). Report of Special Committee on Nutrition B.M.A London.

Chanarin, I., Laidlaw, J., Loughridge, L. W., and Mollin, D. L. (1960).

Brit. med. F., 1, 1099. 51, 757 .

Dacie, J. V. (1956). Practical Haematology, 2nd ed. Churchill, London. Dawbarn, M. C., Hine, D. C., and Smith, J. (1958). Aust. F. exp. Biol. med. Sci., 36, 511 .

Doig, A., Girdwood, R. H., Duthie, J. J. R., and Knox, J. D. E. (1957). Lancet, 2, 966.

Forshaw, J. (1963). Brit. med. F., 1, 328.

Girdwood, R. H. (1953). Ibid., 2, 741 .

- Read, A. E., McCarthy, C. F., and Waters, A. H. (1963). Quart. f. Med., 32, 243.

Gough, K. R., Mollin, D. L., and Read, A. E. (1962). Paper presented to Scientific Meeting, Royal College of Physicians, London.

Herbert, V. (1962). Arch. intern. Med., 110, 649.

Kay, A. W. (1953). Brit. med. f., 2, 77.
Kohn, J., Mollin, D. L, and Rosenbach, L. M. (1961). F. clin. Path. 14,345 .

Lewis, S. M., and Porter, I. H. (1960). Ann. rheum. Dis., 19, 54.

Matthews, D. M. (1962). Clin. Sci., 22, 101.

McCance, R. A., and Widdowson, E. M. (1960). Spec. Rep. Ser. med. Res. Coun., (Lond.), No. 297.

Mollin, D. L. (1960). Ann. Rev. Med., 11, 333.

Waters, A. H., and Harris, E. (1962). In Vitamin $B_{1}$, and Intrinsic Factor, edited by $\mathrm{H}$. C. Heinrich, p. 737. Enke, Stuttgart.

- Gough, K R., and Read, A. E. (1963). Brit. med. f., 1, 609

(1960). Annual Report, 1958. H.M.S.O.; Landon.

Partridge, R. E. H., and Duthie, J. J. R. (1963). Brit. med. 9., 1, 89.

Read, A. E.. Gough, K. R., Bones, J. A., and McCarthy, C. F. (1962) Lancet, 1, 894

Robson, H. N., and Lawrencc I K (1959). Brit. med. f., 2, 475.

Romine, M. K. (1960). F. Vttaminol., 6, 196.

Schilling, R. F. (1954). Fed. Proc., 13, 769.

Scott, J. T., Porter, I. H., Lewis, S. M., and Dixon, A. St. J. (1961) Quart. F. Med., 30, 167.

Spray, G. H. (1955). Clin. Sci., 14, 661, 667

Waters, A. H., and Mollin, D. L. (1961). 7. clin. Path., 14, 335.

Whiteside, M., Mollin, D. L., Coghill, N. F., and Anderson, B. B. To be published.

Will, J. J., Mueller, J. F., Brodine, C., Kiely, C. E., Friedman, B., Hawkins, V. R., Dutra, J., and Vilter, R. W. (1959). J. Lab. clin. Med., 53, 22.

\title{
Meclozine and Foetal Malformations: A Prospective Study
}

\author{
R. W. SMITHELLS, ${ }^{*}$ M.B., M.R.C.P., M.R.C.P.ED., D.C.H. ; ELIZABETH R. CHINN, † B.A.
}

Meclozine is an antihistamine with a marked anti-nausea and anti-sickness effect. It is contained in three proprietary preparations marketed in Great Britain: "ancolan" $(25 \mathrm{mg}$. meclozine), "ancoloxin" (25 mg. meclozine with $50 \mathrm{mg}$. pyridoxine), and "sea-legs" (12.5 mg. meclozine). The first two of these preparations are widely used for the treatment of pregnancy sickness ; the third is used chiefly for travel sickness.

In December 1962, almost exactly one year after the first reports of the teratogenicity of thalidomide, attention was called to the possibility that meclozine might be causing foetal malformations (British Medical fournal, 1962). The Swedish National Board of Health withdrew the drug from public sale in Sweden and warned doctors not to prescribe it for women in the early months of pregnancy. The evidence which had led them to this decision was not at that time generally available. Almost simultaneously, Watson (1962) published a preliminary report from the Epidemic Observation Unit of the College of General Practitioners in which he referred to "mounting evidence against the safety of ancoloxin in pregnancy."

\section{Methods}

Three groups of pregnancies have been studied, using slightly different techniques. All three were studied prospectively. A few mothers came into more than one group. When these duplicates are excluded we have records of 219 infants born to mothers for whom meclozine was prescribed in the first 12 weeks of pregnancy. In every case the preparation prescribed was ancoloxin.

\section{Series 1}

Early in 1962 a circular letter was sent to all general practitioners practising obstetrics in the Liverpool area, requesting information about pregnant women for whom ancoloxin had

\footnotetext{
* Consultant Paediatrician and Medical Superintendent, Alder Hey Children's Hospital. Lately Lecturer in Child Health, University of Liverpool.

† Research Assistant.
}

been prescribed. The replies included the names of 44 women for whom the drug had been prescribed in the first 12 weeks of pregnancy. For this group the date of the last menstrual period is known, and it has therefore been possible to determine accurately the stage of pregnancy at which the drug was prescribed. It is possible that in this group some of the mothers may not have taken the prescription to the chemist, or may have obtained the tablets but not taken them. However, these prescriptions were issued in 1961 (except for five in January 1962), before the teratogenic effect of thalidomide was known, and it is therefore probable that the majority of these women took the drug. Later, in 1962, after these women had had their babies, the presence of malformations was determined as in Series 2 (below).

\section{Series 2 and 3}

These two series were based on copies of prescriptions kindly provided by the Liverpool Pricing Bureau. All prescriptions for ancoloxin issued in Liverpool in the four-months period November 1961 to February 1962 were used. In several instances prescriptions were issued to the same person on more than one occasion ; in these cases only the earliest known prescription is considered. Steps were taken to determine which of the patients to whom the prescriptions were issued had given birth to children after the appropriate time interval. In these series it is certain that the tablets were issued to the patients, although it is possible that in some instances they may not have been taken. In these two series the date of the last menstrual period is known only if the infant was abnormal, when the information is available from the Congenital Abnormalities Register (see below). In calculating the stage of pregnancy at the time of the prescription a 40-weeks gestation period has been assumed in the case of normal infants. Some of the births will, in fact, have been premature, and in these cases the drug will have been prescribed earlier in pregnancy than estimated. This factor and the assumption of a 40-weeks gestation mean that some mothers of normal babies who took meclozine in the first 12 weeks of pregnancy have been estimated to have taken it 
later and have therefore been excluded. These errors will therefore tend to exaggerate slightly the incidence of malformations in the infants of series 2 and 3.

Series 2 consisted of prescriptions for ancoloxin issued in November and December 1961. There were 408 prescriptions for 352 patients: 56 had to be excluded, largely because of illegibility. Information about the remaining 296 women was provided by health visitors, and it was found that 153 had given birth to babies during the summer of 1962. In 91 of these cases the prescriptions had been issued in the first 12 weeks of pregnancy.

This technique of individual follow-up was very timeconsuming and was therefore modified in Series 3, which used prescriptions issued in January and February 1962. Since the beginning of 1960 the Liverpool Congenital Abnormalities Registry has recorded all infants born in the city with any kind of congenital abnormality (Smithells, 1962). In the second series the health visitors had not discovered any malformations which were not already recorded in the Registry, and it was therefore not felt necessary to have a personal follow-up for the third series. This comprised 380 acceptable prescriptions for 250 patients. Their names and addresses were compared, on the one hand, with the Congenital Abnormalities Register, and, on the other hand, with the statutory birth-notification forms from late May to early November 1962. This revealed that 110 of these women had given birth to infants at the relevant time, and that the drug had been prescribed in the first 12 weeks of pregnancy in 84 cases.

These three series gave a total of 219 infants whose mothers had received meclozine in the first 12 weeks of pregnancy. A more detailed analysis of the stage of pregnancy at which the drug was prescribed is given in the Table. The periods given are days of pregnancy, not days of embryonic life. The method of calculation has been described above.

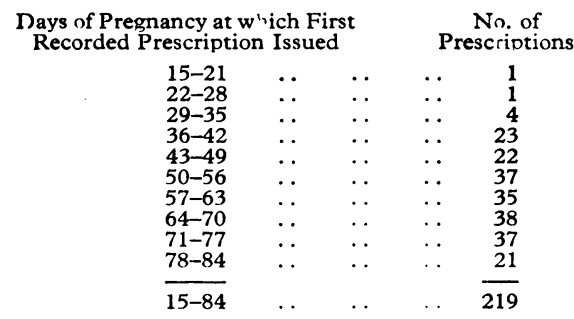

\section{Results}

Significant congenital abnormalities have been detected in only three of these 219 infants. Two of these were diagnosed in the neonatal period ; the third was diagnosed when the infant was a few weeks old. The prescription dates are known to be the first in these pregnancies. One child with a vascular naevus and two children with talipes have been excluded.

Case 1.-Anencephaly. No previous children. The mother has spina bifida occulta (first sacral vertebra): aged 24 years: blood group $\mathrm{B} \mathrm{Rh}$ positive. Last menstrual period began 20 September 1961. Meclozine first prescribed on 7 November (48 days).

Case 2.-Choanal stenosis and post-alveolar submucous cleft palate. Two previous healthy children. Mother aged 24 years: blood group O Rh positive. Last menstrual period began 25 August 1961. Meclozine first prescribed on 25 October (61 days).

Case 3.-Subglottic stenosis. No previous children. Mother aged 21 years: blood group A Rh positive. Last menstrual period 5 July 1961. Meclozine first prescribed on 25 August (51 days).

\section{Comment}

The proportion of infants born with significant congenital abnormalities in Liverpool, as in other parts of the world, lies between 2 and $3 \%$. The total number of three malformed among 219 births in this study does not differ significantly from the expected number.

That two of the three patients (Cases 2 and 3) had stenoses of the respiratory tract is unlikely to be more than coincidence, and a very much larger series would be needed before any useful comment could be made.

Each case needs to be examined to determine whether the timing of the prescription is compatible with the nature of the malformation. The anterior neuropore closes on the 40 th day of pregnancy (26 days from ovulation), and anencephaly must therefore result from some factor operative before this time. In Case 1 meclozine was first prescribed 48 days after the last period and is therefore unlikely to be causally related.

Fusion of the palate is completed by the 77 th day of pregnancy (63 days from ovulation). It is difficult to be certain at what stage choanal stenosis arises, but in Case 2 it probably arose in association with the defective development of the palate. It is therefore possible that meclozine, prescribed at 61 days, could have been causally related.

It is equally difficult to put an exact time on the development of subglottic stenosis, but there is little doubt that the normal growth of the larynx and trachea could be disturbed by some factor operative at the 51 st day of pregnancy (Case 3 ).

\section{Conclusions}

This study provides no evidence to support the suggestion that meclozine may be teratogenic in man. Although it would be more satisfactory to investigate a much larger series before reaching final conclusions, the evidence presented suggests that meclozine may be used for the treatment of pregnancy sickness without any risk of deforming the foetus. Because this drug has hitherto been used so widely, and because 2 to $3 \%$ of infants are born with malformations, there will continue to be instances in which the administration of this drug in early pregnancy will be followed by the birth of an abnormal baby. There is at present no evidence to suggest a causal relationship in such cases.

\section{Summary}

Using information supplied by general practitioners and from prescriptions, 219 pregnancies have been studied prospectively in which ancoloxin was prescribed within the first 12 weeks (84 days) of pregnancy. No abnormality was detected in 216 infants; the remaining three had congenital abnormalities, details of which are given, but in one of these cases the defect must have arisen before the drug was first used.

This study has only been possible because we have been given active help and co-operation by people in every branch of the National Health Service. We would particularly like to thank Professor A. B. Semple, Medical Officer of Health for Liverpool, and his team of health visitors; the chairman and members of the Liverpool Medical Committee; the staff of the Liverpool Pricing Bureau, particularly Miss W. Barclay; the chief clerk and the staff of the Liverpool Executive Council ; and the staffs of the records departments of the Liverpool hospitals. We are also indebted to the United Liverpool Hospitals Research Fund and the National Fund for Research into Poliomvelitis and other Crippling Diseases for grants in support of this work.

ADDENDUM.-Since this paper was submitted a symposium has been published in the Bulletin de la Société Rovale Belge de Gvnécologie et d'Obstétrique (1963, Vol. 33) which includes six studies of meclozine in pregnancy. No teratogenic effect was recorded in any of these papers, which include one from Sweden (Winberg, J., loc. cit., p. 63).

\section{REFERENCES}

Brit med. 7., 1962, 2, 1456.

Smithells, R. W. (1962). Develop. Med. Child. Neurol., 4, 320. Watson, G. I. (1962). Brit. med. F.. 2, 1446. 